\title{
Method (Stimulation Endorphin, Oxytosin and Sugestive) to Increase The Production of Breast Milk and Involution of Uters On Post Partum
}

\author{
Sefrina Rukmawati, Puji Astutik, Ambar Dwi Retnoningrum \\ STIKes Satria Bhakti, Nganjuk, Indonesia \\ *sefrinarkmawati99@gmail.com
}

\begin{abstract}
The purpose of this study was to determine the effect of Method (Stimulation endorphin, oxytocin and suggestive) on breast milk production and uterine involution in post partum. Method: This research uses quasi experiment post test only design. The study used consecutive sampling. The independent variable Method (Stimulation Endorphin,Oxytosin and Sugestive), dependent variable Smoothness of breast milk and Uteric Involution. data collection using observation sheets. The study population and sample were 30 respondents with purposive sampling technique. The results of the study of 30 respondents, 15 respondents were not given speos method therapy almost all respondents, namely 13 respondents not producing smooth milk $(86.6 \%)$ and 10 respondents were abnormal Uterus $(66.67 \%)$, while 15 respondents were given Method (Stimulation endorphin, oxytocin and suggestive) almost All respondents, 14 respondents, were producing breast milk smoothly $(93.3 \%)$. T-test results obtained pvalue $=0,000 \leq \alpha=(0.05)$, so that Ha is accepted. There is an influence of Method (Stimulation endorphin, oxytocin and suggestive) to increase milk production and involution of the uterus in post partum. Method (Stimulation endorphin, oxytocin and suggestive) are proven as efforts that can be done to expedite milk production and uterine involution, so endorphin, oxytocin and suggestive stimulation needs to be applied by midwives and hospital
\end{abstract}

Keywords : Method (Stimulation endorphin, oxytocin and suggestive), Breast Milk Production, Uteric Involution, Post partum

Received August 5, 2020; Revised October 3, 2020; Accepted October 26, 2020 


\section{STRADA Jurnal Ilmiah Kesehatan}

DOI: $10.30994 /$ sjik.v9i2.310

ISSN: 2252-3847 (print); 2614-350X (online)

Vol.9 No.2 November 2020 Page.1207-1211

\section{BACKGROUND}

In Indonesia, the mortality rate of mothers and toddlers is still relatively high. Every day, 803 mothers in the world (in Indonesia as many as 38 mothers based on 305) die from illness / complications due to pregnancy and childbirth. Data from SUPAS: Indonesia is one of the countries with the highest MMR in ASEAN, namely 305 / 100,000 live births, and as many as $150 / 1000$ births. And as many as 7,000 newborn babies die every day (Indonesia: 185 / day with AKN 15/1000 live births) [1].

Where $47 \%$ of under-five deaths are Neonatal deaths. Where one of the factors causing the high maternal mortality rate (MMR) in Indonesia one of them is postpartum bleeding. Factors causing infant death are lack of breastfeeding for infants [2]. The mother tends to give formula milk to her baby due to breast milk production, if an incident like this is not addressed it will have an impact on the health of th e baby, where babies who are not breastfed will tend to be more susceptible to infection and get sick compared to children who are breastfed [3]. One way to overcome the smooth milk and prevention of bleeding is effect of Method (Stimulation endorphin, oxytocin and suggestive) on breast milk production and uterine involution in post partum. This technique will stimulate the release of the hormone oxytocin where the oxytocin hormone plays a role for the removal of milk and can make uterine muscle contractions so that the involuntary uterine process runs normally [4]. In the study the effect of Method (Stimulation endorphin, oxytocin and suggestive) on breast milk production and uterine involution in post partum had an influence on the production of breast milk and infant weight gain and the results of the study had an influence on the production of breast milk and the increase in infant weight in postpartum [5].

In Nurul Kamariyah's research entitled "Psychological conditions can affect the milk production of breastfeeding mothers, this study analyzes how the relationship between maternal psychology and the smoothness of breastfeeding in mothers in conducting research shows a significant value, namely there is a relationship between maternal psychology and the smoothness of breastfeeding in breastfeeding mothers, wherein the better the psychological the mother, the better the production will be [6].

\section{METHODS}

This study uses a Quasy design post test only experiment [7]. The intervention group was treated with the of Method (Stimulation endorphin, oxytocin and suggestive), starting 1- 6 hours post partum every day until the 10th day while the control group was not intervened. The sampling technique used consecutive sampling [8]. namely post partum mothers who came sequentially and met the inclusion criteria, namely post partum mothers with spontaneous labor, post partum mothers without complications and birth weight of babies> 2500 grams.

The of Method (Stimulation endorphin, oxytocin and suggestive)was carried out by researchers with the principle of massage around the back parallel to the breast accompanied by positive suggestions with the aim of stimulating the hormone oxytocin to help expedite the release of milk and uterine involution. Expenditures for breastmilk and breast milk using the observation sheet measuring instrument which contains an evaluation checklist of the 10th day. For the removal of breastmilk with many indicators of breast milk can seep through the nipple, before breastfeeding the mother feels tense the mother can hear the sound of slow swallowing when the baby swallows breast milk, the mother can feel the flow of breast milk every time the baby starts to suckle and the Fundus Uteri Height is measured by the indicator of the Decreased Uterus Height. 


\section{STRADA Jurnal Ilmiah Kesehatan}

DOI: $10.30994 /$ sjik.v9i2.310

ISSN: 2252-3847 (print); 2614-350X (online)

Vol.9 No.2 November 2020 Page.1207-1211

Method (Stimulation Endorphin,Oxytosin and Sugestive), dependent variable Smoothness of breast milk and Uteric Involution The committee of Ethical Approval in Institut of Health Science Strada Indonesia has carefully revieved the research and approved this research with fullboard.

\section{RESULT}

Table 1. Data Tabulation Effect of Stimulation, Endorphin, Oxytocin And Suggestion Methods on breast milk production

\begin{tabular}{ccc}
\hline breast milk production & Control & Therapy \\
\hline Yes & 2 & 2 \\
\hline No & 13 & 13 \\
\hline Total & 15 & 15 \\
\hline Statistical Test Results $\rho$ & 0,000 &
\end{tabular}

Based on Table 1 it can be seen that the production of breast milk in the control group is the result of a study of 30 respondents, 15 respondents were not given therapy and 15 respondents were given therapy and almost all respondents were not given therapy, namely 13 respondents were not Current (86.6\%). while 15 respondents were given the of Method (Stimulation endorphin, oxytocin and suggestive). Almost all respondents, 14 respondents, produced breast milk smoothly (93.3\%). The t-test statistic results obtained pvalue $=0,000$ (p-value $\alpha$ ) so that Ha is accepted which can be concluded that there is an influence of the of Method (Stimulation endorphin, oxytocin and suggestive) on breast milk production

Table 2. Data Tabulation Effect of Speos Method (Stimulation, Endorphin, Oxytocin And Suggestive) on Uteric Involvement

\begin{tabular}{ccc}
\hline Uteric Involvement & Control & Therapy \\
\hline Normal & 5 & 14 \\
\hline Abnormal & 10 & 1 \\
\hline Total & 15 & 15 \\
\hline Statistical Test Results $\rho 0,000$ & \\
\hline
\end{tabular}

Based on table 2 it can be seen that uterine infusion in the control group is 30 respondents, 15 respondents were not given therapy and 15 respondents were given therapy. Of the 15 respondents who were not given therapy, there were $10(66.67 \%)$ respondents who were involuntary uterine abnormally while from 15 respondents who were treated there were $14(93 \%)$ respondents who were involusio uterine normal. The results of the t-test statistic obtained p-value $=0,000$ (p-value $\alpha \alpha$ ) so that $\mathrm{Ha}$ is accepted which can be concluded that there is an influence of the of Method (Stimulation endorphin, oxytocin and suggestive)on the Uteric Involution.

\section{DISCUSSION}

Based on Table 1 it can be seen that the production of breast milk in the control group is the result of a study of 30 respondents, 15 respondents were not given therapy and 15 respondents were given therapy and almost all respondents were not given therapy, namely 


\section{STRADA Jurnal Ilmiah Kesehatan}

DOI: $10.30994 /$ sjik.v9i2.310

ISSN: 2252-3847 (print); 2614-350X (online)

Vol.9 No.2 November 2020 Page.1207-1211

13 respondents were not Current $(86.6 \%)$. while 15 respondents were given the of Method (Stimulation endorphin, oxytocin and suggestive) on breast milk production Therapy. Almost all respondents, 14 respondents, produced breast milk smoothly (93.3\%). The t-test statistic results obtained p-value $=0,000$ (p-value $\alpha \alpha$ ) so that Ha is accepted which can be concluded that there is an influence of the Stimulation, Endorphin, Oxytocin and Suggestion methods on breast milk production.

Method (Stimulation endorphin, oxytocin and suggestive) on breast milk production and uterine involution in post partum mothers, which stimulate the realease of the hormon oxytocin throught, providing comfort and fostering confidence in mather that breast mil must come out and mothers can provide exclusive breastfeeding with endoephin and suggestive massage [4]. In Nurul Kamariyah's research entitled "Psychological conditions can affect the milk production of breastfeeding mothers, this study analyzes how the relationship between maternal psychology and the smoothness of breastfeeding in mothers in conducting research shows a significant value, namely there is a relationship between maternal psychology and the smoothness of breastfeeding in breastfeeding mothers, wherein the better the psychological the mother, the better the production will be [6]

Oxytocin massage is one solution to overcome the smooth production of breast milk [3]. Massage is massage along the spine (vertebrae) to the fifth-sixth costae bone and is an attempt to stimulate the hormone prolactin and oxytocin after childbirth, This massage serves to increase the hormone oxytocin which can calm the mother, so that milk automatically comes out [4]. With this massage in the spinal region will also relax tension and relieve stress and thus the hormone oxytocin will come out and will help the release of breast milk, assisted by baby sucking on the nipple as soon as the baby is born with a normal baby, dripping colostrum or exit is a sign of active oxytocin reflex [5].

Oxytocin massage can be done whenever the mother wants with a duration of 3-5 minutes, preferably done before breastfeeding or milking milk. So as to get the optimal and good amount of breast milk.

Based on the results of this study it can be concluded that the influence of oxytocin massage on milk production [5]. This happens because Oxytocin Massage can increase the hormone oxytocin which can calm the mother so that breast milk automatically comes out. With this massage in the spinal region will also relax tension and relieve stress and thus the hormone oxytocin will come out and will help the release of breast milk, assisted by baby sucking on the nipple as soon as the baby is born with a normal baby, dripping colostrum or exit is a sign of active oxytocin reflex [9].

Based on table 2 it can be seen that uterine infusion in the control group is 30 respondents, 15 respondents were not given therapy and 15 respondents were given therapy. Of the 15 respondents who were not given therapy, there were $10(66.67 \%)$ respondents who were involuntary uterine abnormally while from respondents who were treated there were 14 (93\%) respondents who were involusio uterine normal.

Endorphin massage can increase the production of the hormone oxytocin where the hormone is very functional against uterine contractions, if uterine contractions are adequate to eat will cause acceleration in the process of uterine involution [3]. according to Coad \& Dunnstall in the research of uterine involutional process in the puerperium states the rate of decline in height of the fundus uteri, which normally drops $1 \mathrm{~cm}$ a day. Effects of Oxytocin (Contractions) The intensity of uterine contractions increases significantly soon after the baby is born, thought to occur in response to a very large decrease in intrauterine volume [5]. The oxytocin hormone released from the pituitary gland strengthens and regulates uterine contractions, compresses blood vessels and helps the 


\section{STRADA Jurnal Ilmiah Kesehatan}

DOI: $10.30994 /$ sjik.v9i2.310

ISSN: 2252-3847 (print); 2614-350X (online)

Vol.9 No.2 November 2020 Page.1207-1211

process of hemostasis [10]. Uterine muscle contractions and retractions will reduce the blood supply to the uterus. This process will help reduce placental implantation scars and reduce bleeding [6].

\section{CONCLUSION}

There is an influence of endorphin, oxytocin and suggestive stimulation to increase milk production and uterine involution in post partum mothers. Endorphin, oxytocin and suggestive stimulation methods are proven as efforts that can be done to accelerate milk production and uterine involution, so endorphin, oxytocin and suggestive stimulation needs to be applied by midwives and hospitals.

\section{ACKNOWLEDGMENT}

The researcher thanked because this research was funded by Kementrian Ristek Dan Teknologi/ Badan Riset Dan Inovasi Nasional

\section{REFERENCES}

[1] Departemen Kesehatan, "Kematian Maternal and neonatal in Indonesia," 2019.

[2] Departemen kesehatan, "Kematian Maternal and neonatal in indonesia," 2019.

[3] Perry S. E \& Cashion K., Lowdermilk D. L., Keperawatan Maternitas, 8th ed. singapore, 2013.

[4] Saleha, Asuhan Kebidanan pada Masa Nifas. Jakarta: Salemba Medika, 2009.

[5] DE Nugraheni and Heryati K, "Metode SPEOS (Stimulasi pijat endorpin Oksitosin Sugestif) dapat meningkatkan produksi ASI peningkatan berat badan bayi," Jurnal Kesehatan, vol. 8, pp. 1-7, 2013.

[6] Ambarwati, Asuhan Kebidanan Masa Nifas. Jogjakarta: Mitra Cendikia Press, 2010.

[7] Sopiyatun M Dahlan, Statistik untuk kedokteran dan kesehatan, 4th ed. Jakarta: Salemba Medika, 2009.

[8] Sugiyono, Metodologi penelitian Kurantif, Kualitatif, dan R\&D. Bandung: Alfabeta CV, 2017.

[9] Prawirodiharjo, Ilmu Kebidanan. Jakarta: PT Bina Pustaka sarwonodiharjo, 2010.

[10] Widyasih Hesty Suherni, Rahmawati, and Anita, Perawatan Masa Nifas. jogjakarta: Fitramaya, 2009. 